\title{
Political Realism in St Augustine of Hippo's Theology of Original Sin: Some Practical Considerations
}

\author{
Blazio M. Manobo' \\ 1 Department of Systematic Theology, Catholic University of Zimbabwe, Harare-Zimbabwe.
}

\begin{abstract}
The problem of evil has preoccupied religious and secular discussions for centuries. All religions of the world have tried to proffer explanations of how evil came into the world and whether human beings are evil by nature or by imitation. Modern Political realism has waded into the discussion with the assertion that human beings inherited selfishness, pride, egocentricity from their first parents. Some proponents of political realism find justification in the Judeo-Christian theology of St Augustine of Hippo whose theology of Original sin traces the origins of evil to Adam's sin. This paper seeks to establish the relationship between modern political realism and St Augustine's theology of Original sin. Using a historical-critical and hermeneutic approach, the article argues that the evil committed by political realists cannot be justified through St Augustine's theology of Original sin. It further asserts that rather than having a limiting effect, the doctrine of Original sin can be a liberating notion. Consequently, the study concludes that the moral evil of selfishness exuded by politicians stems not from human beings' nature as free human beings but from their nurture and maybe changeable by recourse to the doctrine of Original sin.
\end{abstract}

Correspondence

Blazio M. Manobo Email: b.manobo@gmail.com

Publication History Received 21st June, 2021 Accepted 15th November, 2021 Published online 8th February, 2022

Keywords: Realism, Original sin, evil, Augustine

(C) 2022 The Author(s). Published and Maintained by Noyam Publishers.

This is an open access article under the CCBY license (http://creativecommons.org/licenses/by/4.0/).

\section{INTRODUCTION}

Politicians are known to have a penchant for electoral fraud, political violence corruption and deceit. ${ }^{1}$ African countries are caught up in a myriad of socio-economic underdevelopment due to leadership crises. The African continent is ranked as the richest in the world in terms of natural resource endowments. The continent boasts of $30 \%$ of the world's known reserves of minerals; $10 \%$ of oil and $8 \%$ of the world's gas resources; the largest cobalt, diamonds, platinum, and uranium reserves in the world; and $70 \%$ of columbitetantalite deposits. ${ }^{2}$ Instead of providing pathways to development, Africa's natural resource curse has led to political violence, murders, genocides, coups and conflicts. Regrettably, some African leaders hide behind political realism ${ }^{3}$ built on a faulty understanding of St Augustine's theory of Original sin. No longer do

1 Arthur F. Chikerema and Vincent Chakunda, "Political Culture and Democratic Governance in Zimbabwe," Journal of Power, Politics \& Governance, 2 no.1, (2014), 55.

2 Eric M. Kumeh, Natural Resource governance in Africa. Tana Forum. 2017, accessed June 5, 2021.

https://www.researchgate.net/publication/318788425_Natural_Resource_Governance_in_Africa

3 Zoltán Gábor Szücs, “The a-heoretical Core of Political Realism”. Studies in Social and Political Thought 28 (2019): $30-45$. https://doi.org/10.20919/sspt.28.2018.91. 
African leaders experience the guilt of abusing power for selfish purposes because they feel helpless due to their participation or inheritance of Adam's $\sin ^{4}$

Globally, most religions of the world have attempted to proffer enlightenment on how evil came into the world and whether human beings are evil by nature or by imitation. The discussion has been split into the social sciences with theories in politics and international relations using religion to justify inhuman atrocities like the Nazi holocausts in Germany (1942), the Rwandan genocide (1994), the Gukurahundi genocide in Zimbabwe (1983-7), the United States 9/11 bombing, and many other moral evils committed by states and non-state actors for political reasons. Some proponents of political realism find justification for human evil in the Judeo-Christian theology of St Augustine of Hippo. ${ }^{5}$

World events of the First World War (1919) and Second World War (1940) have pushed political realists to critique the nobility, plausibility and praxis of idealism as offering objective explanations to international political conflicts. ${ }^{6}$ World conflicts like the Iranian and Iraqi wars (1980-1988), the US-Iraq war (2003), the Libyan war (2011), and the Syrian war (2011-2020), among others, demonstrate the futility of idealism in explaining the source of human propensity towards conflict. The selfishness and egocentricity exuded by nation states at the international level are well reflected at the local level where politicians would do whatever it takes to amass power.

The political realist Nicolas Machiavelli is deemed to be the "representative par excellence of the lack of morality and ethics in politics." As Lamus points out, just as the name Machiavelli means "total lack of scruples', hence, the extreme realist's philosophy is built around the conviction that politics is all about murder, lying, treachery, malice, deceit, conspiracy and disloyalty to achieve political goals. It is worth investigating whether such characterizations are born of the nature of human beings and whether the self-interest of politicians can be explained in terms of the sin of Adam and Eve. According to St. Thomas Aquinas, as reported by O'Neil, sin is an act not in accord with reason informed by the divine law while evil is defined as a privation of form or order or due measure. ${ }^{8}$ In making a theological analysis of the source of human conflicts in political discourses, this article will be guided by Gottfried Wilhelm Leibniz's distinctions of three types of evil where he postulates that, 'Evil may be taken metaphysically, physically and morally. Metaphysical evil consists in mere imperfection, physical evil in suffering, and moral evil in sin." This article makes a deliberate attempt to discuss political manipulations and treachery as moral evils (sin) whose nature calls for liberation. The article is delimited to discussions on the extent to which St. Augustine's theology of Original sin can liberate humankind from their inclination towards crimes against themselves and against the environment. It is not within the scope of this article to provide a comprehensive theological exposition of St. Augustine's political thought or his theology of Original sin. Neither is the article going to provide a detailed analysis of realism as applied in international politics. Rather, the article attempts to answer the question: Can St. Augustine of Hippo's theology of Original sin be used to justify political evil? Using Leibniz's definitions, the notions of sin and evil will be used interchangeably.

\section{Background to the theology of Original sin}

St. Augustine of Hippo who developed the notion of Original sin was born on 13 November 354 at Carthage in North Africa being the son of Patricius and Monica. He studied Latin grammar, arithmetic, Roman prose, philosophy, and poetry. He later taught rhetoric in Milan. He became a Christian at the age of 32 and was

Genesis 3:1ff.

5 Filipe Lamus, Machiavelli's Moral Theory: Moral Christianity versus Civic Virtue. (Graduate liberal studies: Duke University, 2016), 15.

6 Poowin, Bunyavejchewin. "Theories of International Politics after the Incident of 9/11: The Richness and Weakness of Realist Tradition in the Twentieth-First Century”. Kasetsart Journal of Social Sciences, 33(1), (2012): 161.

Lamus, Machiavelli's Moral Theory: Moral Christianity versus Civic Virtue, 15.

8 Charles Arthur O’Neil, Sin. In The Catholic Encyclopaedia. New York: Robert Appleton Company, (1912), accessed May 21, 2021.http://www.newadvent.org/cathen/14004b.htm

9 Yair, Hoffman, "Jeremiah 50-51 and the Concept of Evil in the Hebrew Bible” In H. G. Reventlow and Y. Hoffman. (eds), The Problem of Evil and its Symbols in Jewish and Christian Tradition (T\&T Clarke: London, 2004), 15. 
consecrated Bishop of Hippo in Algeria in 395 A.D. He wrote his famous work, City of God between 413-427 where he seemed to suggest that there would be no political authority had Original sin not been committed. ${ }^{10}$ Augustine died in 430 A.D. in Algeria and was canonized saint in 1303 by Pope Boniface XIII. As Jesse Couenhoven ${ }^{11}$ noted, what is now understood as Augustine's doctrine of Original sin is a handful of doctrines with a conceptual core of the notion of inherited $\sin ^{\prime 12}$

Original sin is a Christian doctrine coined and developed by St. Augustine that describes both the sin that Adam committed and "the consequence of this first sin, the hereditary stain with which we are born on account of our origin or descent from Adam"13 This article shall not attempt to carry out an exegesis of the first three chapters of Genesis where the sin of Adam is recorded but shall delimit itself to the consequence of that sin which constitutes St. Augustine's doctrine of Original sin. Augustine was not the originator of the concept of Original sin. Augustine only reinterpreted the Bible in the light of philosophy and the earlier writings of Church Fathers like Irenaeus, Origen and Tertullian and coined the term Original $\sin$.

Two foundational background theories to the theology of Original sin of interest to this study can be cited here: the first being the biblical account of the origin of sin, and the second being the Augustinian Manichean background. The first account presents the link between human sin and the Genesis account of Adam's fall. It also demonstrates how Augustine seemed to have been heavily influenced by Paul's writings to the Romans. In the second account, one can find the influence of the Manicheans on Augustine's thoughts and how he later fought against them. Manicheanism was later declared a Christological heresy. ${ }^{14}$ Manicheanism is an early century Christian theological heresy that taught a dualistic view of good and evil subscribing to the view that the omnipotent God, as opposed to the earthly forces of evil power.

The Bible contains several episodes that attest to the dilemma about the existence of evil without attempts to explain why human beings find themselves trapped in this evil. Only in the book of Exodus, does one find an allusion to inherited sin with no reference to the sin of Adam and Eve, where it says; "For I, the Lord your God, am a jealous God, inflicting punishment for their fathers' wickedness on the children of those who hate me, down to the third and fourth generation" 15 Despite this association, the Old Testament does not link human sin to the sin of Adam and Eve but conceives sin as infidelity to God's covenants. ${ }^{16}$

In the books of Kings, several accounts of Israel's decline due to evil actions perpetrated by kings with no link to first parents can be observed. Episodes like; the apostasy of King Solomon (1 Kgs 11.113 ), the division of the kingdom (1 Kgs 12), the deterioration of the northern kingdom (2 Kgs 17), the fall of Judah, the sack of Jerusalem, the burning of the Temple, and the end of the Davidic dynasty. In all these accounts, reference is made to people's failure to observe the covenant demands. In the prophetic tradition, readers encounter a situation where people are solely responsible for their actions and will be answerable individually to God (Ezek 18:4, Jeremiah 31:29-30). All these episodes support the view that the Old Testament conception of evil was not tied to the Genesis narratives of the sin of Adam and Eve alone.

Paul, writing to the Romans declared that, "Therefore, just as through one man sin entered the world, and death through sin, and thus death spread to all men, because all sinned" (Rom. 5:12 NRSV). According to Paul, the state of creation is not what God intended it to be. Paul believes that creation was subjected to the evil power of Satan who rules it by the power of death and corruption. ${ }^{17}$ Paul affirms that death followed $\sin$. Adam and Eve passed death from sin to their offspring. Consequently, every person shares the sin of

10 Paul. J Weithman, “Augustine and Aquinas on Original sin and the Function of Political Authority," Journal of the History of Philosophy, 30(3), (1992), 354.

11 Jesse Couenhoven, “St. Augustine's Doctrine of Original sin”. Augustinian Studies. 36(2), (2005):358.

12 Charles Mathewes, Evil in Augustinian Tradition. (Cambridge: Cambridge University Press, 2001), 34.

13 Catholic encyclopedia online. "Original sin" Available at https://www.newadvent.org/

14 Couenhoven, "St. Augustine's Doctrine of Original sin," 362.

15 Exodus 20:5 (New Revised Standard Version)

16 Peter B. Ely, Adam and Eve in Scripture, Theology, and Literature: Sin, Compassion, and Forgiveness (London: Lexicon Books, 2018), 67.

17 John. S. Romanides, “Original sin according to St Paul”, St. Vladimir’s Seminary Quarterly, 4(1) (2015), 1959. 
Adam and Eve and is destined to die. Using the same passage, Paul makes it clear that sin leads to death. Even though Paul's focus was not directed towards Adam's guilt but the situation that gave rise to the need for salvation, his theology had a profound impact on the development of the notion of Original sin as later adopted by St. Augustine.

Another important milestone in Augustine's theology of Original sin was his association with the Manicheans. The Manichean religion was founded by the prophet Mani in Persia (216-277 A.D.). Mani claimed a revelation from God that led him to teach the heresy that believers will be given secret knowledge which shall be hidden from the non-believers. This knowledge will lead to their salvation. For Mani, this world is an arena for opposing forces of good and evil. He argued that the physical world is associated with darkness and is the manifestation of evil while light manifests good. This teaching, which in the history of the Church is associated with Gnosticism, was condemned as heresy for it assumes that this world is evil and not worthy of redemption. ${ }^{18}$

Augustine had acquainted himself with his Manichean Bishop, Faustus, and read the Manichean literature during his teens. It is recorded that what attracted Augustine to the Manicheans was not their theological position but their Christian piety. The Manichean heresy is said to have influenced St. Augustine in his conceptualization of human nature as inherently sinful due to the sin of Adam. ${ }^{19}$ However, St. Augustine later wrote intensely against the Manichean heresy demonstrating his divergent thinking away from the heretical teachings of Manichaeans.

\section{St. Augustine's Theology of Original sin}

Augustine considered Original sin to mean the sin that Adam committed which has become a hereditary stain human beings are born with on account of their descent from Adam. Augustine was convinced that "the deliberate sin of the first man is the cause of Original sin." ${ }^{20}$ Rowan Greer interprets this teaching to mean that all humans are born moving away from $\mathrm{God}^{21}$ and that "the doctrine does not merely claim that all adult human beings are sinners, having sinned at some point or another; more radically, it maintains that all human beings are born culpably misrelated to God." ${ }^{22}$ It is from this perspective that Augustine was convinced of salvation in Christ through baptism justifying infant baptism since, for him, all people sinned in Adam.

Augustine was aware that infants have no capacity for personal sin and cannot be held responsible for the sins they did not commit. For him, if God would judge human beings on such counterfactuals, then, the incarnation would lose its significance. For Augustine, the logic of the incarnation and infant baptism is only meaningful in the context of an Original sin. This justifies Augustine's assertion that, "if infants can be justified without their own activity through Christ, they can also become sinners without their consent, through the first Adam, and the parental activity of conception." ${ }^{23}$ Summarily, Augustine's doctrine of Original sin states that the primal sin in the Garden of Eden was the source of Original sin and that because of solidarity with Adam, all human beings share in this sin. As a result of this solidarity, humankind inherit this sin at birth in the form of common guilt, and a constitutional fault of disordered desire and ignorance.

Augustine's theology of Original sin raised quite a number of contestations. Central to these contestations is the argument that the notion is unworthy of a loving God. ${ }^{24}$ That the sin of Adam is the cause of death was first denied by Theodorus of Mopsuestia and later influenced Celestius who claimed that "Adam was to die in every hypothesis, whether he sinned or did not sin. His sin injured himself only and not

18 Van H. Oort, “Augustine and Manichaeism: New discoveries, new perspectives”. Verbum et Ecclesia JRG 27(2), (2006), 722.

19 James O’Donnell, “St Augustine: Christian Bishop and Theologian” Encyclopaedia Britannica (2020) accessed February 13, 2021.

20 St Augstine. De nupt. et concup., II, xxvi, 43).

21 Rowan. A. Greer, Christian Life and Christian Hope: Raids on the Inarticulate. (New York: The Crossroad Publishing Company, 2001): 120.

22 Couenhoven, “St. Augustine's Doctrine of Original sin”, 358.

23 Couenhoven, "St. Augustine's Doctrine of Original sin,"361.

24 Ely, Adam and Eve in Scripture, Theology, and Literature, 67. 
the human race." ${ }^{25}$ These criticisms were shared by Pelagius (who was eventually condemned at Carthage) as fundamentally flawed. In correcting this heterodoxy, the Church cited Romans 5:12, where Adam is exposed as diffusing death with sin. The Pelagians later accepted that the sin of Adam transmitted death but they rejected the transmission of sin. According to the Pelagians, when Paul speaks of the transmission of sin, he meant death. Later they accepted the transmission of sin as the hereditary stain contracted at birth which adults commit in imitation of Adam. The Pelagius notion was finally put to rest by the Council of Trent (1545-1563) that condemned Pelagianism and declared that the sin of Adam is transmitted to all by generation and not by imitation. Since then, the Church interprets Augustine's theological position by teaching that,

The doctrine of Original sin, closely connected with that of redemption by Christ, provides lucid discernment of man's situation and activity in the world. By our first parents' sin, the devil has acquired a certain domination over man, even though man remains free. Original sin entails "captivity under the power of him who thenceforth had the power of death, that is, the devil". Ignorance of the fact that man has a wounded nature inclined to evil gives rise to serious errors in the areas of education, politics, social action and morals. ${ }^{26}$

This means the consequences of Original sin and of all personal sins put the world as a whole in the sinful condition that manifests itself as the negative influence exerted on people by communal situations and social structures that are the fruit of men's sins.

\section{Re-interpreting St. Augustine's theology of Original sin}

At the centre of the biblical book of Genesis' Adamitic mythology, is the sin of the first parents that connotes an acknowledgement that the world is not as good as it should be and that human beings are not as they would like to be. St Paul writing to the Romans (7:14-15) confessed that there is a struggle between his inner desires and his external actions, for often, he finds himself doing the opposite of the good he harbours in his heart. Can such contradictions justify atrocities like exploitation, war, abuse, cruelty and genocide in human history? What influence has the notion of Original sin had in modern political realism? The failure to understand St. Augustine's notion of Original sin has negatively affected the modern world in several areas including colonialism, political violence, and gender violence among others.

\section{Colonialism}

The colonialism of the $19^{\text {th }}-20^{\text {th }}$ century has left an indelible mark on the lives of many third-world countries. In the African continent, the colonialists whose work was made easier by the accompanying missionaries who in many cases made Christian conversion look more like European Capitalist conversion were responsible for the plunder of African resources. ${ }^{27}$ Ocheni and Nwankwo ${ }^{28}$ observed that, "the deep-seated corruption in most African states and the selfish behavior of some of the political leaders to sit tight in office even when they have obviously outlived their usefulness in the eyes of their people, are attributable to the effects of colonialism and imperialism".

Political realism in international relations argues that nations often prioritize national interest above collective values. Countries will do whatever it takes to satisfy their electorates irrespective of the consequences to the other state. In this regard, the realism of the colonialists led to the subjection of Africans to severe oppression while the imperial masters plundered the African resources. The historical subjugation of Africans can never be explained within the context of human propensity to the evil emanating from Original sin. St Augustine's notion of Original sin fails to justify the dominion of a weaker society by the other. On the contrary, in his book The City of God, Augustine asserts that servitude is a condition or

25 Stephane Harent, “Original sin”. In The Catholic Encyclopedia. (New York: Robert Appleton Company. 1911). Accessed June 12, 2021 http://www.newadvent.org/cathen/11312a.htm

26 Catechism of the Catholic Church, 2nd ed., (Vatican: Libreria Editrice, 1992)

27 Global Black History. "Role of missionaries in colonization of Africans," (2012). https://www.globalblackhistory.com/

28 Stephen. Ocheni \& Basil Nwankwo, “Analysis of Colonialism and Its Impact in Africa”. Cross-Cultural Communications, $8(3)(2012), 46$. 
institution not found in "the order of nature" in which God created man. God, intended human beings to exercise dominion or dominiura only over irrational creatures, and not over other human beings." 29 Hence, Original sin does not imply that human beings have no control over their free will. Rather, they have limited control over their irresistible pressure to act wrongly.

\section{Political Violence}

Augustine's theory of inherited guilt sought to explain why even the saints had to struggle with their passions to remain good. The theory does not justify the abuse of human beings as means to achieve one's end. Political violence rides on the debate of the 'means' and 'ends.' Human beings were never meant to be used as means to an end. The famous political realist Machiavelli, commenting on the question on whether it is better to be feared or loved, declared that for a Prince, "one should wish to be both, but, because it is difficult to unite them in one person, is much safer to be feared than loved, when, of the two, either must be dispensed with." ${ }^{30}$ Realists believe in deterrence theories through the use of violence. African political leaders often seem to subscribe to the realism of Machiavelli by instilling fear into the minds of their followers as a means to attain political stability. This is well demonstrated in Africa where few countries have managed to hold free and fair elections devoid of violence.

Political violence is a deliberate outcome of a rational process by rational human beings. The sin of Adam only demonstrates some spiritual weakness arising out of man's tainted nature. However, the decisionmaking process is a matter of free will where one is free to use his/her lucid and cogent faculties to decide on the right course of action. The Institute for Security Studies (ISS) has warned that the ballot and not the gun is becoming the source of political violence in Africa. ${ }^{31}$ This implies that the desire to use other human beings through violence as a means to achieve personal political expediency is likely to increase in Africa putting to rest prospects for peace and development. The question arises as to why such prospects for political violence are higher in Africa than in other continents if Augustine's notion of Original sin is universally applicable.

\section{Gendered Original sin}

Another common misreading of the theory of Original sin is found in how the text on Original sin has been used to derogate women. For centuries, women have suffered blame based on the assumption that Eve was responsible for Adam's sin. Even St Augustine himself had a pessimistic view of sex drawn from his earlier promiscuous life. To a greater extent, Augustine believed Original sin is transmitted from generation to generation through the sexual act. ${ }^{32}$ Since then, the sexual act became intricately united with the temptation of Adam by Eve. This is then demonstrated by how women are treated in politics. According to Kumar women legislators constitute only $23 \%$ of all parliamentarians throughout the world, yet they are the majority. ${ }^{33}$

Feminist theologian Patricia Wismerobserved that, "the very account of Original sin in the Bible, which scape-goats women, and as a result disables them further in the face of male violence against them, can itself be viewed as part of this Original sinfulness." ${ }^{34}$ Often feminists have argued that men formulated the doctrine of sin devoid of the experience of women. As a result, men have found in the sin of Eve the reason to oppress women and to disqualify them as equal partners. This supports the observations of O'Sullivan that Original sin for men is pride and power over and against women and for women its self-relegation and an under-valuation of the self. ${ }^{35}$ Consequently, the realist misreading of St Augustine's theory of Original sin

29 Weithman, "Augustine and Aquinas on Original sin and the Function of Political Authority", 356.

30 Niccolo Machiavelli, \& D. Wootton, The Prince. (Indianapolis: Hackett Pub. Co., 1995), 36.

31 Jakkie Cilliers, Violence in Africa: Trends, drivers and prospects to 2023. (Sweden, Institute for Security Studies, 2018$), 1$.

32 Stephen Greenblatt, "How St Augustine invented sex", Annals of Culture, (2017), 6.

33 Pankaj Kumar, "Participation of Women in Politics: Worldwide experience," Journal of Humanities and Social Science (IOSR-JHSS), 22, 12(6), (2017), 77.

34 Patricia Wismer, L, "For Women in Pain: A Feminist Theology of Suffering," In the Embrace of God: Feminist Approaches to Theological Anthropology (New York: Maryknoll, Orbis Books, 2005), 154.

35 James O’Sullivan, “Catholics Re-examining Original Sin in light of Evolutionary Science: The State of the question. New Black Friars, 99(1083), (2016): 674. 
will justify women inequality as divinely ordained.

\section{Original sin in modern politics}

As has been noted above, the concept of Original sin does indeed present some theological challenges for its failure to provide answers to the origin of the primal sin of Adam. This begs the question; what caused Adam to sin when sin did not exist prior to Original sin? The simple answer to this puzzle is that human nature is the basis of morality. The mythological character of the sin of Adam must be understood in the context of man's alienation from God. Here, it will be worth quoting the basic moral principle derived from the teaching of the Church that says, "the laws of morality are not rules that we make but principles that we discover, like the laws of a science such as anatomy: they are based on human nature, and human nature is essentially unchanging, and therefore the laws of morality are also essentially unchanging, like the laws of anatomy." ${ }^{" 36}$ For this reason, nurture plays a significant role in shaping individual free will.

While the theory of Original sin seems to portray God as a vindictive God who punishes people for the sin they did not commit, the doctrine must be understood from its mythological character. Augustine did not intend to provide an interpretation of a malicious God. For Augustine, despite authoring the doctrine of Original sin, he understood evil as the privation of goodness that cannot be attributed to God. Augustine firmly believed that evil comes from the human free will that is also capable of choosing good. ${ }^{37}$ Therefore, political realists must understand Original sin not as a historical fact but as a portrait of human alienation from God. The responsibility to abstain from political machinations like violence, murder, rape, genocide all reside in man's inability to use positively his free will.

Augustine's theory of Original sin was meant to explain the human propensity towards evil desires. It demonstrates that 'sin entered human history by a misuse of freedom, and the remedy for sin also began through a free decision'. The teaching was necessary for defending infant baptism, a teaching that was recently defended by Pope Benedict XVI in April 2007, through a report of the commission that declared that there are "reasons to hope that infants who die without baptism may be saved and brought into eternal happiness" 38 . The theory also serves to demonstrate that humanity cannot attain salvation outside the grace of God in Christ. Christians are reminded by Paul that grace is much more powerful than sin, "for where sin increased, grace abounded all the more" (Rom 5:20). As the teaching of the church says, "Grace precedes, prepares and elicits our free response. It responds to the deep yearnings of human freedom, calls for its cooperation and leads freedom toward its perfection." 39

Political realism is an afront to the Christian principle of the common good. From the Social Teachings of the Church, one learns that humans are only stewards of the resources that have been made available. The resources on this earth are enough for everyone if they are shared equitably. Also, humans are distinguished from animals by their rational nature. One does acknowledge that humans have a weak nature. However, the choice for political evil is an abuse of man's rational nature due to the doctrine of free will. As Pope Francis has posited,

Grace, precisely because it builds on nature, does not make us superhuman all at once. That kind of thinking would show too much confidence in our own abilities. Unless we can acknowledge our concrete and limited situation, we will not be able to see the real and possible steps that the Lord demands of us at every moment, once we are attracted and empowered by his gift. Grace acts in history; ordinarily, it takes hold of us and transforms us progressively. If we reject this historical and progressive reality, we can actually refuse and block grace, even as we extol it by our words. ${ }^{40}$

36 Peter Kreeft, Human nature as the Basis of Morality (New Haven: Catholic information Centre, 2001 ), 5.

${ }^{37}$ Hsun Guo and Hu, Xiajun, "Evil Human Nature: From the Perspectives of St. Augustine and Hsun Tzu," Open Journal of Philosophy, 1(2), (2011): 62

38 Pope Benedict, The hope of salvation for infants who die without being baptised. Vatican: International theological commission.(2007).

39 Catechism of the Catholic Church, 2nd ed. (Vatican: Libreria Editrice, 2018), no. 468

40 Pope Francis, Gaudete et exsultate, (2018) no. 158. 


\section{CONCLUSION}

The article posited that political evil perpetrated by human beings in this world is not divinely ordained. Human beings have the capacity to transform this world into a habitable planet. What St Augustine taught by his doctrine of the original sin is that human beings are under the strain of sinful desires. However, this assertion did not imply incapacitation to achieve the moral good as through free will, people are able to live morally upright lives. Political realism as a theory in politics and international relations provides an explanation on behaviours by individuals and nation states that cannot be used to justify political evils of violence against citizens.

There is great potential for Africans to adopt transformative politics where the wellbeing of citizens is given priority over individual gains. Africa's development remains premised on good governance built on democratic principles. Political violence cannot be the solution to political expediency as it creates more violence. Consequently, this study makes the following recommendations; First, politics is about creating an enabling environment for all citizens irrespective of their sex, race, or status through freedoms and participation. Politicians must understand that human freedom can only be attained in an atmosphere where the rights of individuals are respected. Second, development is about people. National development correlates with peace and good governance. African politicians should understand that by inflicting violence on others, they too suffer alienation that comes with a lack of dignity. Finally, evil exists among human beings, and politicians must help advocate for structures that promote peace and reconciliation among the people as foundations of a dignified society.

\section{BIBLIOGRAPHY}

Bunyavejchewin, Poowin. "Theories of International Politics after the Incident of 9/11: The Richness and Weakness of Realist Tradition in the Twentieth-First Century". Kasetsart Journal of Social Sciences, 33(1), (2012): $161-169$.

Catechism of the Catholic Church (2nd ed.). Vatican: Libreria Editrice, 2018.

Chikerema, Arthur. \& Chakunda, Vincent. "Political Culture and Democratic Governance in Zimbabwe". Journal of Power, Politics \& Governance, 2(1), (2014): 55-66.

Cilliers, Jakkie. Violence in Africa: Trends, drivers and prospects to 2023. Sweden, Institute for Security Studies, 2018.

Couenhoven, Jesse. "St. Augustine's Doctrine of Original sin". Augustinian Studies. 36(2), (2005): 359-396. doi: https://doi.org/10.5840/augstudies200536221

Ely, Peter. B. Adam and Eve in Scripture, Theology, and Literature: Sin, Compassion, and Forgiveness. London: Lexicon Books, 2018.

Global Black History. "Role of missionaries in colonization of Africans". (2012). https://www.globalblackhistory.com/role-of-missionaries-in-colonization-of-africans/

Greer, Rowan. A.. Christian Life and Christian Hope: Raids on the Inarticulate. New York: The Crossroad Publishing Company, 2001. doi: https://doi.org/10.1177/004057360205900215

Guo J. Hsun, and Hu, Xiajun. "Evil Human Nature: From the Perspectives of St. Augustine and Hsun Tzu". Open Journal of Philosophy, 1(2), (2011): 61-66. doi: https://doi.org/10.4236/ojpp.2011.12011

Harent, Stephane. "Original sin”. In The Catholic Encyclopedia. New York: Robert Appleton Company. 2020. Accessed June 12, 2021 https://www.newadvent.org/cathen/11312a.htm

Hoffman, Yair. "Jeremiah 50-51 and the Concept of Evil in the Hebrew Bible" In H. G. Reventlow and Y. Hoffman. (eds). The Problem of Evil and its Symbols in Jewish and Christian Tradition. T\&T Clarke: London, 2004.

Kreeft, Peter. Human nature as the Basis of Morality. New Haven: Catholic information Centre, 2001. Kumar, Pankaj. "Participation of Women in Politics: Worldwide experience". Journal of Humanities and Social Science (IOSR-JHSS), 22, 12(6), (2017): 77-88. 
Kumeh, E. Mensah. Natural Resource governance in Africa. Tana Forum. (2017). Accessed May 12, 2021. https://www.researchgate.net/publication/318788425 Natural Resource Governance in Africa

Lamus, Filipe. Machiavelli's Moral Theory: Moral Christianity versus Civic Virtue. Graduate liberal studies: Duke University, 2016.

Machiavelli, Niccolo., \& Wootton, D. The prince. Indianapolis: Hackett Pub. Co., 1995.

Mathewes, Charles. Evil in Augustinian Tradition. Cambridge: Cambridge University Press, 2001.

Ocheni, Stephen. and Nwankwo, Basil. "Analysis of Colonialism and Its Impact in Africa". Cross-Cultural Communications, 8(3) (2012): 46-54.

O’Donnell, James. "St Augustine: Christian Bishop and Theologian". Encyclopaedia Britannica (2020). Accessed February 13, 2021.

O’Neil, Arthur.Charles. Sin. In The Catholic Encyclopaedia. New York: Robert Appleton Company, 2020, Accessed May 21, 2021.http://www.newadvent.org/cathen/14004b.htm

Oort, H. Van "Augustine and Manichaeism: New discoveries, new perspectives". Verbum et Ecclesia JRG 27(2), (2006): 709-729. DOI: https://doi.org/10.4102/ve.v27i2.172

O'Sullivan, P. James. "Catholics Re-examining Original Sin in light of Evolutionary Science: The State of the question. New Black Friars, 99(1083), (2016): 653-674. doi: https://doi.org/10.1111/nbfr.12234

Romanides, John. S. “Original sin according to St Paul”. St. Vladimir's Seminary Quarterly, 4(1) (2015): 1955-6.

Szücs, Zoltán Gábor. “The a-heoretical Core of Political Realism”. Studies in Social and Political Thought 28 (2019). doi: https://doi.org/10.20919/sspt.28.2018.91.

Weithman, Paul. J. “Augustine and Aquinas on Original sin and the Function of Political Authority". Journal of the History of Philosophy, 30(3), (1992): 353-376. doi: https://doi.org/10.1353/hph.1992.0058

Wismer, L. Patricia. "For Women in Pain: A Feminist Theology of Suffering," In the Embrace of God: Feminist Approaches to Theological Anthropology. New York: Maryknoll, Orbis Books, (2005), 138-158.

\section{ABOUT AUTHOR}

Blazio Manobo $(\mathrm{PhD})$ is a Senior Lecturer at the Catholic University of Zimbabwe specializing in Systematic Theology with special research interests in Theology and development, Eco-theology, and liberation theology. He has published several articles in international journals and book chapters on systematic theology and published a book on 'The Future of Religious Life in Africa: Trials and Visions'. 